\title{
Elasmobranch Distribution and Assemblages in the Southern Tyrrhenian Sea (Central Mediterranean)
}

Bottari T, Busalacchi B, Profeta A, Mancuso $\mathbf{M}^{*}$, Giordano D and Rinelli P

Institute of Coastal Marine Environment (IAMC) - CNR, Spianata S. Raineri, 86 - 98122 Messina, Italy

\begin{abstract}
The aim of this study is to identify elasmobranch species present in the SouthernTyrrhenian Sea, to describe their distribution and abundance, to identify significant spatial or temporal differences between species. 14 bottom trawl surveys were carried out from 1994 to 2007. 16 species of elasmobranchs were recorded. Multidimentional Scaling Ordination (MDS) showed two groups according to the depth gradient: in the first one the stations from upper slope and in the second one the stations from middle slope. Mean biomass indices and frequency of occurrence showed that Galeus melastomus, Etmopterus spinax and Scyliorhinus canicula were the most abundant species. Mean biomass indices for other species were very low. The mean abundance of G. melastomus exhibited a positive temporal trend in biomass and density. The mean abundance of $E$. spinax exhibited a negative temporal trend in biomass and in density. For other species abundance varied greatly between years, even if there was no evident trend.
\end{abstract}

Keywords: Sharks; Ecosystem; Trawl surveys; Multivariate analysis

\section{Introduction}

In the Mediterranean Sea there is a high level of exploitation due to a great variety of fishing gears; generally the elasmobranchs are not targeted by commercial fisheries but they are an important by-catch especially of the trawl fishery and deep-water long liners [1-4].

The decreases in abundance and biomass of some elasmobranch species throughout the last decade have been reported in the Gulf of Lions $[5,6]$.

The role of these species as indicators of fishing pressure has been suggested $[4,7,8]$ and management strategies are necessary to minimize significantly the chondrichthyan by-catch.

This paper characterizes the assemblages of demersal elasmobranch on the bottom trawl fishing grounds along the Southern Tyrrhenian Sea. Experimental trawl surveys are analysed for the main species in terms of species composition, community structure and distribution.

This paper could be useful for monitoring future trends in the same area and would allow comparison with other seas.

\section{Materials and Methods}

\section{Study area and sampling design}

Data here reported come from 14 bottom trawl surveys, carried out during the MEDITS Project, from 1994 to 2007 in the Southern Tyrrhenian Sea. The study area extended from Cape Suvero to Cape S. Vito (Figure 1), within the isobath of 800 metres, for a total area of $7256 \mathrm{~km}^{2}$. Only $65 \%\left(4716 \mathrm{~km}^{2}\right)$ of the total area studied can be trawled by commercial vessels. The fishing fleet is represented by 80 trawlers providing about 5000 tons of fish, molluscs and crustaceans (IREPA2008).

The bottom of this area is characterized by a narrow continental shelf, sometimes entirely missing and by a steep slope [9]. Sampling procedures were the same in all surveys, according to MEDITS project protocol [10]. Sampling was carried out randomly and the hauls were proportionately distributed in five bathymetric strata: stratum A: 1050 metres $\left(622 \mathrm{~km}^{2}\right)$; stratum B: $51-100$ metres $\left(1003 \mathrm{~km}^{2}\right)$; stratum C: 101-200 metres $\left(1224 \mathrm{~km}^{2}\right)$; stratum D: 201-500 metres $\left(1966 \mathrm{~km}^{2}\right)$; stratum E: $501-800$ metres $\left(2441 \mathrm{~km}^{2}\right)$. A total of 360 hauls were carried out. An experimental sampling gear with a cod-end mesh size of 20 millimetres was used. The fishing speed was 3 knots. The horizontal and vertical openings of the net (on average 18.4 and $1.90 \mathrm{~m}$ respectively) were measured using a SCAMMAR system. The haul length was 30 min in the shelf $(10-200 \mathrm{~m})$, and $60 \mathrm{~min}$ in the slope $(>200 \mathrm{~m})$. All elasmobranch species caught were identified, counted and weighed.

\section{Data processing}

Spatial and abundance analyses were employed to investigate temporal trend. In particular, two abundance indexes, mean density index (DI; $\mathrm{N} / \mathrm{km}^{2}$ ) and mean biomass indices $\left(\mathrm{BI} ; \mathrm{kg} / \mathrm{km}^{2}\right)$, were estimated (for each stratum and overall area) according to the swept-area principle [11].

Data were analysed in terms of multivariate analysis using the package Primer v6 [12]. Analyses were carried out on density index. In order to examine the demersal elasmobrach assemblages distribution along space, time and depth, the Multi Dimensional Scaling (MDS) ordination method was employed. The Bray-Curtis similarity index was used on square root transformed data.

The analysis of Similarity (ANOSIM) [13] was applied to detect differences between depths (strata) and time (years). The typifying and discriminating species of the MDS stations were determined using the similarity percentage analysis (SIMPER) [13].

The DI by haul were interpolated and mapped for the three most abundant species. The GIS software ArcMap ${ }^{\mathrm{TM}} 9.0$ (ESRI) was used. An "exact interpolator" (Inverse Distance Weighted) was employed to

*Corresponding author: Monique Mancuso, Institute of Coastal Marine Environment (IAMC) - CNR, Spianata S. Raineri, 86-98122 Messina, Italy, Tel: 0906015438; E-mail: monique.mancuso@iamc.cnr.it

Received November 26, 2013; Accepted December 30, 2013; Published January 07, 2014

Citation: Bottari T, Busalacchi B, Profeta A, Mancuso M, Giordano D, et al. (2014) Elasmobranch Distribution and Assemblages in the Southern Tyrrhenian Sea (Central Mediterranean). J Aquac Res Development 5: 216 doi:10.4172/2155 9546.1000216

Copyright: $\odot 2014$ Bottari T, et al. This is an open-access article distributed under the terms of the Creative Commons Attribution License, which permits unrestricted use, distribution, and reproduction in any medium, provided the original author and source are credited. 
Citation: Bottari T, Busalacchi B, Profeta A, Mancuso M, Giordano D, et al. (2014) Elasmobranch Distribution and Assemblages in the Southern Tyrrhenian Sea (Central Mediterranean). J Aquac Res Development 5: 216 doi:10.4172/2155-9546.1000216

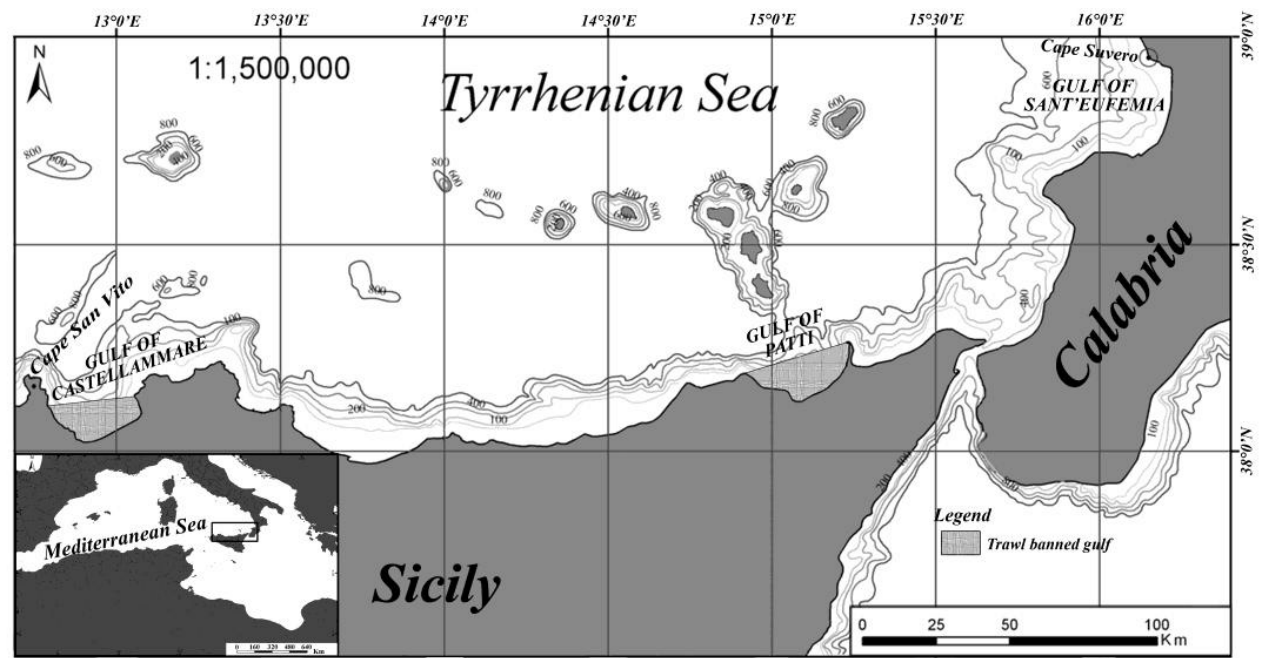

Figure 1: Map of the study area.

\begin{tabular}{|c|c|c|c|}
\hline Species & Family & Order & Common name \\
\hline Galeus melastomus Rafinesque, 1810 & Scyliorhinidae & Carchariniformes & Blackmouth catshark \\
\hline Scyliorhinus canicula (Linnaeus, 1758) & Scyliorhinidae & Carchariniformes & Small-spotted catshark \\
\hline Scyliorhinus stellaris (Linnaeus, 1758) & Scyliorhinidae & Carchariniformes & Nursehound \\
\hline Squalus acanthias Linnaeus, 1758 & Squalidae & Squaliformes & Piked dogfish \\
\hline Etmopterus spinax (Linnaeus, 1758) & Etmopteridae & Squaliformes & Velvet belly \\
\hline Dalatias licha (Bonnaterre, 1788) & Dalatiidae & Squaliformes & Kitefin shark \\
\hline Dasyatis pastinaca (Linnaeus, 1758) & Dasyatidae & Rajiformes & Common stingray \\
\hline Pteroplatytrygon violacea (Bonaparte, 1832) & Dasyatidae & Rajiformes & Pelagic stingray \\
\hline Myliobatis aquila (Linnaeus, 1758) & Myliobatidae & Rajiformes & Common eagle ray \\
\hline Dipturus oxyrinchus (Linnaeus, 1758) & Rajidae & Rajiformes & Longnosed skate \\
\hline Raja clavata Linnaeus, 1758 & Rajidae & Rajiformes & Thornback ray \\
\hline Raja miraletus Linnaeus, 1758 & Rajidae & Rajiformes & Brown ray \\
\hline Raja montagui Fowler, 1910 & Rajidae & Rajiformes & Spotted ray \\
\hline Raja polystigma Regan, 1923 & Rajidae & Rajiformes & Speckled ray \\
\hline Torpedo marmorata Risso, 1810 & Torpedinidae & Torpenidiformes & Spotted torpedo \\
\hline Torpedo torpedo (Linnaeus, 1758) & Torpedinidae & Torpenidiformes & Common torpedo \\
\hline
\end{tabular}

Table 1: Elasmobranch species identified in the Southern Tyrrhenian Sea during the Medit project from 1994 to 2007.

\begin{tabular}{|c|c|c|c|c|c|c|}
\hline \multicolumn{3}{|r|}{ Species } & Av. abundance & Av. Similarity & \multicolumn{2}{|c|}{$\operatorname{sim} / S D$} \\
\hline \multirow{4}{*}{$\begin{array}{l}\text { D stratum: } 201-500 \mathrm{~m} \\
\text { E stratum: } 501-800 \mathrm{~m}\end{array}$} & \multirow{2}{*}{ Av. Similarity: 48.75} & Galeus melastomus & 3.1 & 32.24 & \multicolumn{2}{|l|}{1.34} \\
\hline & & Scyliorhinus canicula & 1.78 & 13.2 & \multicolumn{2}{|l|}{0.81} \\
\hline & \multirow{2}{*}{ Av. Similarity: 72.36} & Galeus melastomus & 3.28 & 40.95 & \multicolumn{2}{|l|}{2.62} \\
\hline & & Etmopterus spinax & 2.41 & 30.68 & \multicolumn{2}{|l|}{2.28} \\
\hline & & Species & \multicolumn{2}{|c|}{ Average abundance } & Av. dissimilarity & Diss/SD \\
\hline \multirow{5}{*}{$\begin{array}{l}\text { D stratum: } 201-500 \mathrm{~m} \\
\text { vs E stratum: } 501-800 \mathrm{~m}\end{array}$} & \multirow{5}{*}{ Av. Dissimilarity: 56.6} & Etmopterus spinax & 0.21 & 2.41 & 17.68 & 2.17 \\
\hline & & Galeus melastomus & 3.1 & 3.28 & 13.64 & 1.28 \\
\hline & & Scyliorhinus canicula & 1.78 & 0.38 & 13.26 & 1.27 \\
\hline & & Scyliorhinus stellaris & 0.75 & 0.08 & 6.21 & 0.54 \\
\hline & & Torpedo marmorata & 0.46 & 0 & 3.8 & 0.54 \\
\hline
\end{tabular}

Table 2: SIMPER analysis results.

render back the real value in every sample site of the studied area [14]. Mean distribution maps were produced pooling the records of surveys from 1994 to 2007.

The correlation between DI and BI values and years was tested using the Spearman's rank-order correlation $(\rho)$.
The distribution of elasmobranches in relation to depth was analyzed comparing the density index by Kruskal-Wallis test.

\section{Results}

16 elasmobrach species were recorded (Table 1). The orders 
Citation: Bottari T, Busalacchi B, Profeta A, Mancuso M, Giordano D, et al. (2014) Elasmobranch Distribution and Assemblages in the Southern Tyrrhenian Sea (Central Mediterranean). J Aquac Res Development 5: 216 doi:10.4172/2155-9546.1000216

observed were: Rajiformes (8 species), Squaliformes (3 species), Carcharhiniformes ( 3 species) and Torpediniformes ( 2 species).

MDS ordination (Figure 2) showed the stations reporting the stratum. Two main groups were distinguished: in the first one the stations from upper slope (201-500 metres) and in the second one the stations from middle slope (501-800 metres) (ANOSIM test: Global $\mathrm{R}=0.6 ; \mathrm{p}<0.01)$.

To individuate the importance of time in order to discriminate the assemblages one-way ANOSIM tests were performed for "year" factor across all "stratum" groups respectively. Each depth stratum was treated separately. There were no differences, across "stratum" groups and between "year" groups (Global R: 0.182 p>0.05).

The results of the SIMPER analysis highlighted the species that mainly contribute as a percentage to similarity within groups "stratum" (Table 2). Galeus melastomus and Scyliorhinus canicula were important in typifying the demersal fish community of D stratum $(201-500 \mathrm{~m})$. The analysis performed on E stratum (501-800 m) showed that, although G. melastomus was still present, Etmopterus spinax also contributed to typifying the group.

SIMPER analysis indicates dissimilarity between assemblages (average dissimilarity: 56.6). The pool of species responsible for discriminating these groups was mainly constituted by E. spinax, $G$. melastomus and S. canicula.

In Figure 3 distribution is shown of the three most abundant elasmobranch species in the Southern Tyrrhenian Sea over 14 years. G. melastomus and E. spinax are more abundant in the eastern and western part of the study area, specifically outside the Gulf of S. Eufemia and in the areas bordering the Gulf of Castellammare; these species were also abundant in an area localized between Sicily and Calabria, in correspondence with the Strait of Messina. G. melastomus and E. spinax were also present inside and outside the Gulf of Patti respectively.

S. canicula was more equally distributed in the study area and like the other two species, was particularly present outside the Strait of Messina.

The mean abundance of G. melastomus exhibited a positive temporal trend in biomass and density (Spearman $\rho: 0.543, \mathrm{p}<0.05$ and $\rho: 0.587, \mathrm{p}<0.05$ respectively). Instead the mean abundance of $E$. spinax

\section{$\Delta$}

2D Stress: 0,16

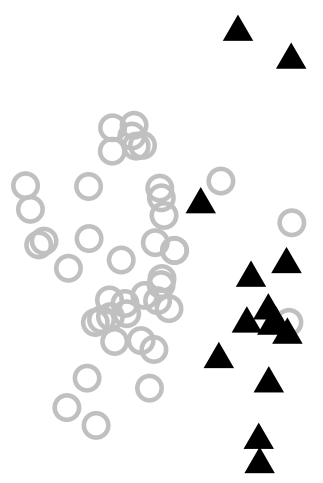

Figure 2: Non-metric Multidimentional Scaling Ordination (MDS) of the sampling stations according to depth. Triangles are the hauls in the upper slope (200 - 500 metres); circles are the hauls in the middle slope (500 - 800 metres).
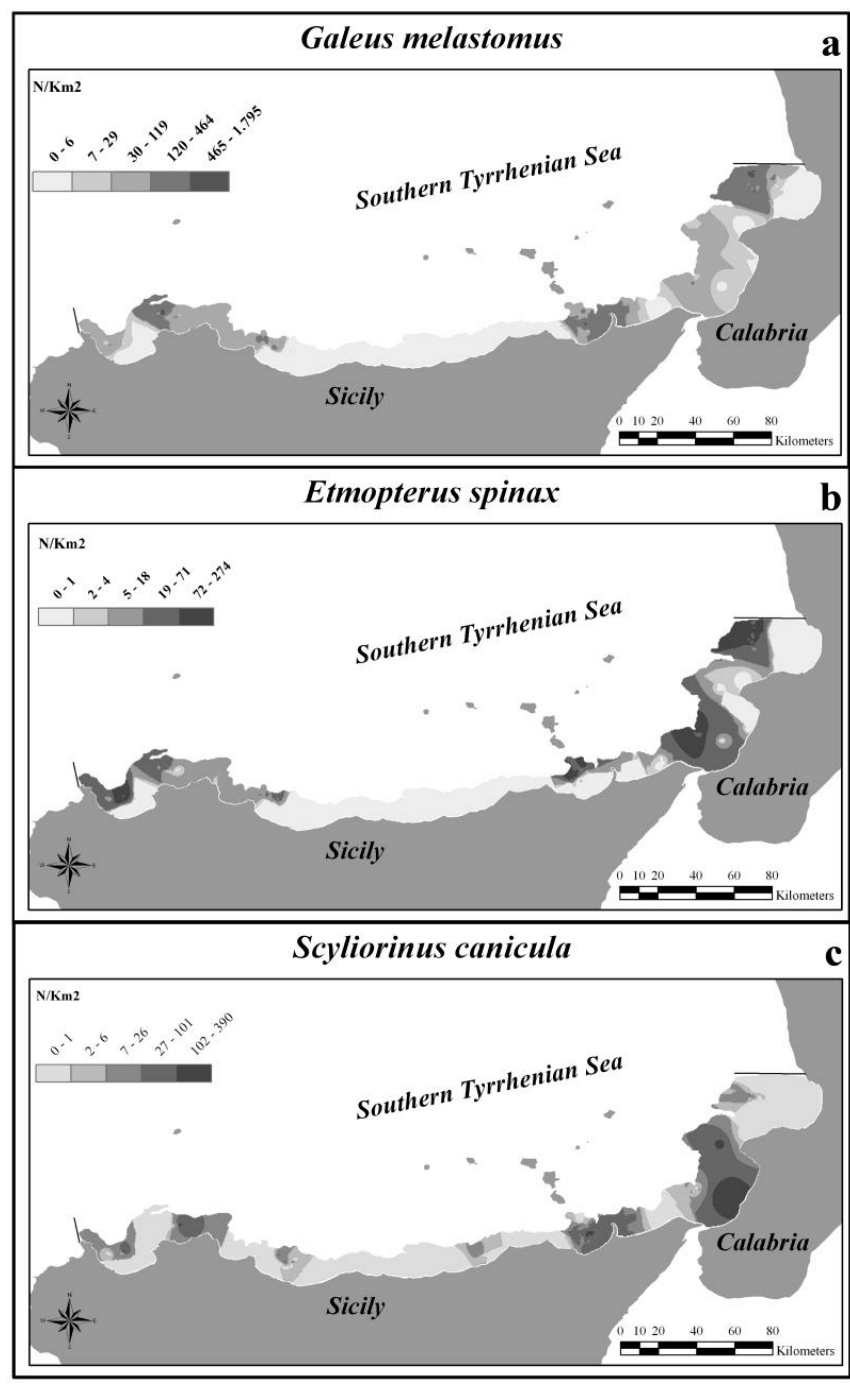

Figure 3: Distribution of (a) Galeus melastomus, (b) Etmopterus spinax, and (c) Scyliorinus canicula along the Southern Tyrrhenian Sea over 14 years.

exhibited a negative temporal trend in biomass (Spearman $\rho:-0.565$, $\mathrm{p}<0.05)$ and in density (Spearman $\rho:-0.661, \mathrm{p}<0.05)$. For other species, abundance varied greatly between years (Figure 4 ).

Abundance appeared to be greatest for G. melastomus deeper than $400 \mathrm{~m}$, for E. spinax deeper than $450 \mathrm{~m}$ and for S. canicula at 300-450 m. However, differences in abundance were statistically significant only for G. melastomus (Kruskal Wallis H: 36.1, p $<0.01$ ). and E. spinax (Kruskal Wallis $\mathrm{H}$ : $57.1, \mathrm{p}<0.01)$. In comparison $S$. canicula was more evenly distributed with respect to depth (Kruskal Wallis H: 14.7, p>0.05) (Figure 5).

\section{Discussion}

The analysis of demersal elasmobranch species in the Southern Tyrrhenian Sea has shown that demersal elasmobranch assemblages are aligned with depth. These results are similar to those obtained in the Atlantic Ocean [15] and in the Western Mediterranean [16] The most important boundary, located around $500 \mathrm{~m}$, separates the species of the upper slope from those of the middle slope down to $800 \mathrm{~m}$. The bathymetric boundaries are similar with those obtained in previous 

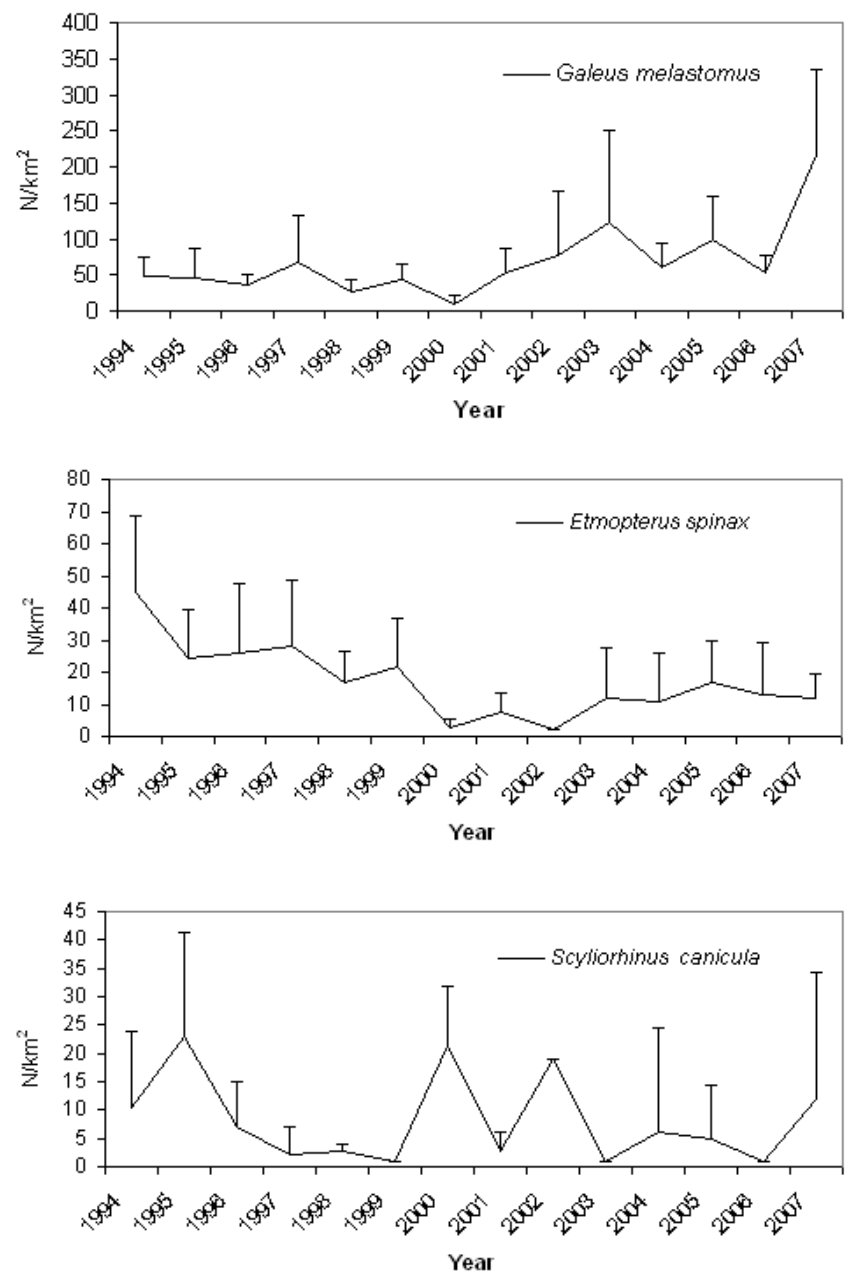

Figure 4: Mean abundance (N/km2) and standard error of the most abundant species from the trawl surveys of 1994-2007.

studies of demersal assemblages carried out in the Southern Aegean [17] and North West Mediterranean [18]. Data reported here suggests that the structure of assemblages does not change in over a period of 14 years.

The upper slope assemblage is characterised by G. melastomus and S. canicula. The middle slope assemblage is characterised also by $G$. melastomus, a species with a wide depth range, and E. spinax, a species present only in this assemblage.

Some papers on slope assemblages demonstrate the importance of factors associated to depth rather than depth itself to affect the assemblages structure [19-21]. The depth in fact, may affect other environmental factors, both biological (trophic factors, interspecific competition, predator-prey relationship) and physical (steepness of the continental slope, substrate type, hydrographic condition, dissolved oxygen, light intensity) [22-24]. Recently, shark assemblages changes, related to temperature and salinity modifications of deep-water masses, have been also reported [25].

The significant increase in density and biomass indices shown by G. melastomus has already been reported for the species in the South of Sicily $[26,27]$.

The opposite abundance temporal trends shown by G. melastomus and E. spinax could be explained by comparing their life history traits. Galeus melastomus is a multiple oviparous whereas Etmopterus spinax is a ovoviviparous. The study of length at first maturity has revealed that E. spinax is a late-maturing species [28] and this fact makes these species more vulnerable to exploitation. Also, they do not have the same "catchability" to trawl fishing. The size distribution varies with depth for both species with larger specimens occurring at deeper waters and the smaller ones at shallower waters $[16,26,29]$. Moreover, the wider vertical distribution of G. melastomus (lower than $1000 \mathrm{~m}$ ) might mitigate the fishing pressure as the species lives beyond the usual deepest commercial trawling limit $[26,27]$. G. melastomus shows an increasing abundance in the Southern Tyrrhenian Sea despite the persistent trawling activities [30].

Cartilaginous fish represent a good fraction (about one third) of the by-catch of red-shrimp fishing in the South of Sicily. The most common species are G. melastomus and E. spinax which are caught in over $90 \%$ of the hauls [31]. Generally they are discarded immediately after capture but elasmobranchs may die after capture because of the sudden pressure changes and handling on board [32,33]. We can hypothesize that $E$. spinax may be more sensitive to these events than G. melastomus.

Nevertheless, factors such as competition, changes in oceanographic conditions and changes in food abundance could affect species abundance.

There is lack of studies about distribution and structure of fish
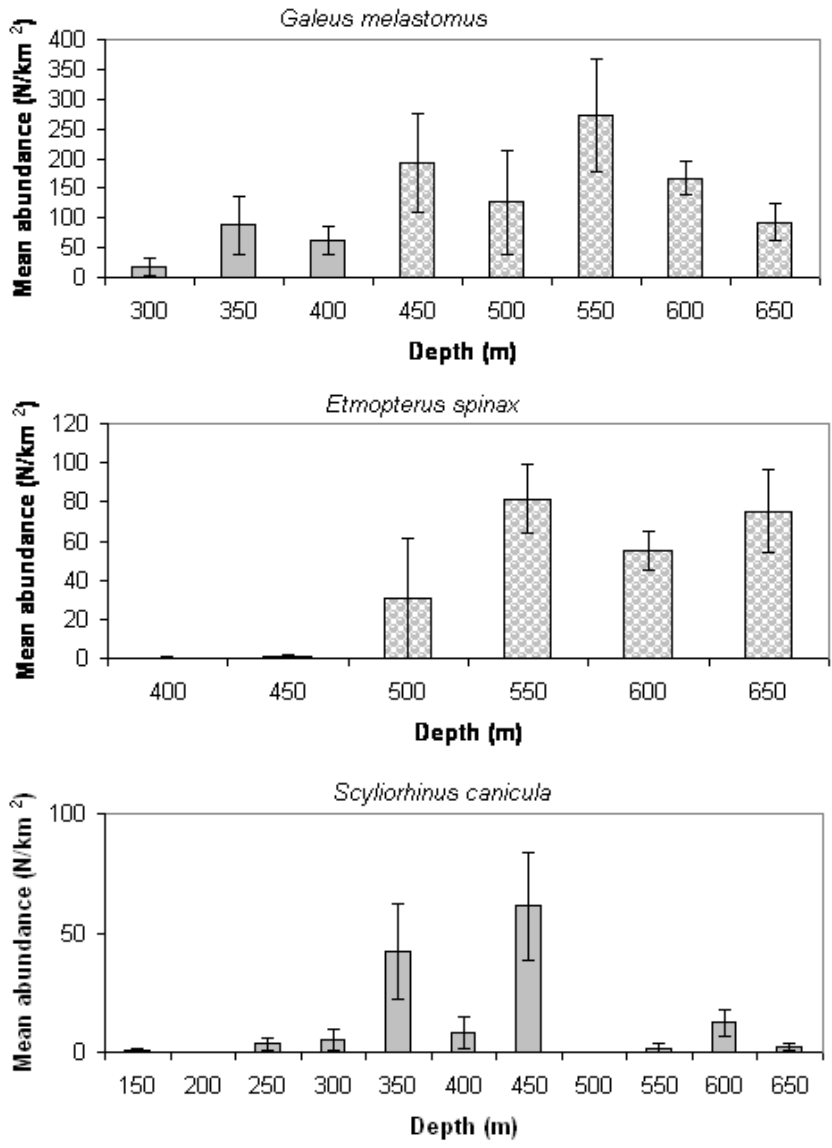

Figure 5: Mean abundance $\left(\mathrm{N} / \mathrm{km}^{2}\right)$ and standard error for the most abundant species in each depth interval in the Southern Tyrrhenian Sea from the trawl surveys of 1994-2007. 
Citation: Bottari T, Busalacchi B, Profeta A, Mancuso M, Giordano D, et al. (2014) Elasmobranch Distribution and Assemblages in the Southern Tyrrhenian Sea (Central Mediterranean). J Aquac Res Development 5: 216 doi:10.4172/2155-9546.1000216

Page 5 of 5

communities in a long temporal scale in most of Mediterranean regions; such studies are necessary for ecosystem based management. We argue that results here reported could be useful as basis for management of fishery activities in the Tyrrhenian Sea.

\section{Acknowledgement}

This paper is a result of the MEDITS Project. We are grateful to all the participants in the Trawl Surveys as well as to the captain and crew of the trawler "Pasquale e Cristina" for their help during the sampling

\section{References}

1. Vacchi M, Notabartolo Di Sciara G (2000) The Cartilaginous Fishes in Italian Seas, A Resource that Urges to be Protected. Biol Mar Medit 7: 296-311.

2. Bertrand J, Gil De Sola L, Papaconstantinou C, Relini G, Souplet A (2000) Contribution on the Distribution of Elasmobrachs in the Mediterranean from the MEDITS Surveys. Biol Mar Medit 7: 1-15.

3. Coelho R, Bentes L, Goncalves J, Lino PG, Ribeito J, Erzini K (2003) Reduction of Elasmobranch By-Catch in the Hake Semipelagic Near-Bottom Longline Fishery in the Algarve (Southern Portugal). Fish Sci 69: 293-299.

4. Carbonell A, Alemany F, Merella P, Quetglas A, Romàn E (2003) The By-Catch of Sharks in the Western Mediterranean (Balearic Islands) Trawl Fishery. Fish Res 61: 7-18.

5. Aldebert $Y$ (1997) Demersal Resources of the Gulf of Lions (Mediterranean) Impact on Fish Diversity. Vie Milieu 47: 275-284.

6. Bertrand JA, Aldebert Y, Souplet A (1998) Temporal Variability of Demersal Species in the Gulf of Lions from Trawl Surveys (1983-1997). IFREMER Actes De Colloq. 26: 153-164.

7. Stevens JD, Bonfil R, Dulvy NK, Walker PA (2000) The Effects of Fishing on Sharks, Rays, and Chimaeras (Chondrichthyans), and Implications for Marine Ecosystems. ICES J Mar Sci 57: 476-494.

8. Rodríguez-Cabello C, Sánchez F, Serrano A, Olaso I (2008) Effects of Closed Trawl Fishery Areas on Some Elasmobranch Species in the Cantabrian Sea. Journal of Marine Systems 72:418-428.

9. Greco S, Rinelli P, Giordano D, Perdichizzi F (1998) Valutazione Delle Risorse Demersali Da Capo Suvero A San.

10. Capo VL (Tirreno Meridionale). Biol Mar Medit 5: 74-84.

11. Anonymous (2012) International MEDITS-Handbook. Revision N. 6, MEDITS Working Group.

12. Gunderson DR (1993) Surveys of Fisheries Resources. John Wiley \& Sons, New York: 248

13. Clarke KR, Gorley RN (2006) Primer V6: User Manual/Tutorial. PRIMER-E, Plymouth.

14. Clarke KR (1993) Non-Parametric Multivariate Analyses of Changes in Community Structure. Aust J Ecol 18: 117-143.

15. Isaaks EH, Srivastava RM (1989) The Effects of Fishing on Marine Ecosystems. Adv Mar Biol 34: 201-352.

16. Roel BA (1978) Demersal Communities off The West Coast of South Africa. S Afr J Marine Sci 5: 575-584

17. Massutí E, Moranta J (2003) Demersal Assemblages and Depth Distribution of Elasmobranchs from the Continental Shelf and Slope off The Balearic Island (Western Mediterranean). ICES J Mar Sci 60: 753-766.

18. Tserpes G, Peristeraki P, Potamias G, Tsimenides N (1999) Species Distribution in the Southern Aegean Sea Based On Bottom-Trawl Surveys. Aquat Living Resour 12:167-175.
19. Massutí E, Reñones O (2005) Demersal Resource Assemblages in the Trawl Fishing Grounds Off The Balearic Islands (Western Mediterranean). Sci Mar 69: 167-181.

20. Stefanescu C, Lloris D, Rucabado J (1993) Deep-Sea Fish Assemblages in The Catalan Sea (Western Mediterranean) Below A Depth of 1000 M. DeepSea Res $40: 695-707$

21. Massutí E, Gordon JDM, Moranta J, Swan SC, Stefanescu C, Merrett NR (2004) Mediterranean and Atlantic Deep-Sea Fish Assemblages: Differences in Biomass Composition and Size-Related Structure. Sci Mar 68 : 101-115.

22. Cartes JE, Maynou F, Lloris D, Gil De Sola L, Garcia M (2009) Influence of Trawl Type on the Composition and Diversity of Deep Benthopelagic Fish and Decapod Assemblages Off the Catalan Coasts (Western). Sci Mar 73 : 725737.

23. Hecker B (1990) Variation in Megafaunal Assemblages on the Continental Margin South of New England. Deep-Sea Res 37: 37-57

24. Smale MJ, Roel BA, Badenhorst A, Field F (1993) Analysis of The Demersal Community of Fish and Cephalopods on The Aguilas Bank, South Africa. J Fish Biol 43 (Suppl.A): 169-191.

25. Sardà F, Cartes JE, Company JB (1994) Spatio-Temporal Variation in Megabenthos Abundance in Three Different Habitats of the Catalan Deep-Sea (Western Mediterranean). Mar Biol 120: 211-219.

26. Cartes JE, Fanelli E, Lloris D, Matallanas J (2013) Effect of Environmenta Variations on Sharks and Other Top Predators in the Deep Mediterranean Sea over the Last 60 Years. Clim Res 55: 239-251.

27. Ragonese S, Nardone GD, Ottonello D, Gancitano S, Giusto GB, Sinacori G (2009) Distribution and Biology of the Blackmouth Catshark Galeus Melastomus in the Strait of Sicily. Medit Mar Sci 10: 55-72.

28. Ragonese S, Vitale S, Dimech M, Mazzola S (2013) Abundances of Demersal Sharks and Chimaera from 1994-2009 Scientific Surveys in the Central Mediterranean. Plos ONE 8: E74865.

29. Coelho R, Erzini K (2005) Length at First Maturity of Two Species of Lantern Sharks (Etmopterus Spinax and Etmopterus Pusillus) Off Southern Portugal. J Mar Biol Ass UK 85: 1163-1165.

30. Rinelli P, Bottari T, Florio G, Romeo T, Giordano D, Greco S (2005) Observations on Distribution and Biology of Galeus Melastomus (Chondrichthyes, Scyliorhinidae) in the Southern Tyrrhenian Sea (Central Mediterranean) Cybium 29: 41-46

31. Mangano MC, Kaiser MJ, Porporato EMD, Spanò N (2013) Evidence of Traw Disturbance on Mega-Epibenthic Communities in the Southern Tyrrhenian Sea. Mar Ecol Prog Ser 475: 101-117.

32. Ragonese S, Di Stefano L, Bianchini ML (2000) Catture E Selettività Di Pesci Cartilaginei Nella Pesca Dei Gamberi Rossi Nello Stretto Di Sicilia. Biol Ma Medit 7: 400-411.

33. Enever R, Catchpole TL, Ellis JR, Grant A (2009) The Survival of Skates (Rajidae) Caught by Demersal Trawlers Fishing in UK Waters. Fish Res 97: 72-76. 